\title{
Comparative descriptive anatomy of the femoral artery in crab-eating fox, hoary fox and maned wolf
}

\section{Anatomia descritiva comparativa da artéria femoral de cachorro-do-mato, raposa-do-campo e lobo-guará}

\author{
Daniela Cristina de Oliveira SILVA²; Lucas de Assis RIBEIRO²; Rodrigo Lopes de FELIPE²; \\ ${ }^{1}$ Universidade Federal de Goiás, Catalão - GO, Brazil \\ ${ }^{2}$ Universidade Federal de Uberlândia, Uberlândia - MG, Brazil \\ ${ }^{3}$ Instituto Federal do Triângulo Mineiro, Uberaba - MG, Brazil
}

Daiane dos Santos de DEUS'; Karime Cássia Silveira GONDIMํㅜ Lázaro Antônio dos SANTOS²; Gustavo Alexandre de Oliveira SILVA ${ }^{3}$; Zenon SILVA ${ }^{1}$; Roseâmely Angélica de CARVALHO-BARROS

\begin{abstract}
The goal of this study was to describe the anatomy of the femoral artery in wild canids such as the crab-eating fox (Cerdocyon thous), the hoary fox (Lycalopex vetulus), and the maned wolf (Chrysocyon brachyurus). Two specimens from each canid group were used. Red dyed latex was injected in the arterial system of the animals, which were then fixed in $10 \%$ formaldehyde aqueous solution and dissected following the routine techniques in macroscopic anatomy. In the three canid groups, the arterial pattern was similar to that described for domestic canids, in which the deep femoral artery rises from the external iliac artery, still in the abdominal cavity, and sends its first branch, the lateral circumflex femoral artery. A few muscular branches, one or two caudal femoral arteries, and the terminal branches - the descending genicular artery, the saphenous artery, and the popliteal artery - are all originated from the femoral artery. The origin pattern of these vessels also shows similarities with those from domestic canids, sometimes forming trunks and occasionally rising individually. Thus, it can be concluded that the anatomical pattern of the femoral artery and its branches in wild canids shows similarities with that from domestic canids, but inherent variations in each species are also present.
\end{abstract}

Keywords: Wild animals. Cerrado mammals. Neotropical canids. Circulatory system.

\section{Resumo}

O objetivo deste estudo foi descrever a anatomia da artéria femoral em canídeos selvagens, como o cachorro do mato (Cerdocyon thous), a raposa do campo (Lycalopex vetulus) e o lobo-guará (Chrysocyon brachyurus). Foram utilizados dois espécimes de cada grupo canídeo. Solução de látex vermelha foi injetada no sistema arterial dos animais, que foram então fixados em solução aquosa de formaldeído a $10 \%$ e dissecados seguindo as técnicas rotineiras da anatomia macroscópica. Nos três grupos canídeos, o padrão arterial foi semelhante ao descrito para canídeos domésticos, em que a artéria femoral profunda origina da artéria ilíaca externa, ainda na cavidade abdominal, e envia seu primeiro ramo, a artéria femoral circunflexa lateral. Alguns ramos musculares, uma ou duas artérias femorais caudais e os ramos terminais - a artéria genicular descendente, a artéria safena e a artéria poplítea - são originários da artéria femoral. O padrão de origem desses vasos também mostra semelhanças com as de canídeos domésticos, às vezes formando troncos e ocasionalmente originando individualmente. Assim, pode-se concluir que o padrão anatômico da artéria femoral e seus ramos em canídeos selvagens mostra semelhanças com a dos canídeos domésticos, mas variações inerentes em cada espécie também estão presentes.

Palavras-chave: Animais selvagens. Mamíferos do Cerrado. Canídeos neotropicais. Sistema circulatório. 
Correspondence to:

Zenon Silva

Universidade Federal de Goiás, Regional Catalão, Instituto de Biotecnologia, Departamento de Ciências Biológicas Av. Dr. Lamartine Pinto de Avelar, 1120 - Setor Universitário CEP 75704-020, Catalão, GO, Brazil

e-mail: zenon_silva@ufg.br

Received: 28/09/2015

Approved: 10/07/2017

\section{Introduction}

The Comparative Anatomy of Wild Animals is a science that has greatly been expanding likely due to its ability to assess the relationships between similar structures and their functions in different taxonomic groups. In addition, the relationships between biome and its components, as well as adaptations and adjustments that can exist among and with other living beings are of great importance in this context (OLIVEIRA et al., 2004).

Cerrado is the second largest Brazilian biome, with over two million square kilometers, and over half of it has been transmuted into agro-pastoral and mining activities. Moreover, only $2 \%$ of its area is under protection of conservation units (RIBEIRO-JUNIOR; BERTOLUCI, 2009). In the Brazilian Cerrado mammals form the second largest group of vertebrates, and among them are the neotropical canids. Although the wild canid population is still considerable, their biology is one of the least known between mammals (CHIARELLO et al., 2008). The anthropogenic pressure on balanced natural biomes boosts the migration of species to non-original areas, forcing them to live with other groups, and they are consequently subjected to various adaptations in order to survive and reproduce in sometimes adverse environments. Often the short life span and various other factors do not favor proper adaptation, which can lead to the risk of extinction (CHIARELLO et al., 2008).

The organization and application of conservation and protection programs are based on the knowledge of the biology of biome components (GANEM, 2011). Considering that studies on the anatomy of the circulatory system in wild canids are rare in the literature, the aim of this work was at describing the anatomy of the femoral artery in neotropical canids, comparing it with domestic animals', humans', and non-human primates.

\section{Materials and Methods}

This is a descriptive and comparative study, in which the dissected structures are described and analysed, comparing data of the studied wild canids with those of domestic canids from the literature. The data were collected through the dissection of two specimens of each wild canid group: crab-eating fox (Cerdocyon thous), hoary fox (Lycalopex vetulus), and maned wolf (Chrysocyon brachyurus). The specimens were road-kill victims and were collected on the margins of Goiás and Minas Gerais highways (Authorization SISBIO 37072/2).

In the Anatomy Laboratory, the arterial system was injected with red-dyed latex "Art Cola" to facilitate visualization of the arteries in order to be studied. Subsequently, specimens were fixed with $10 \%$ formaldehyde aqueous solution and stored in this same solution. The preparation of the anatomical pieces was performed through routine techniques in macroscopic anatomical studies.

The photographic record was made using a digital camera (Sony CyberShot 7.2 megapixels). The Nomina Anatomica Veterinaria (ICVGAN, 2012) was the used nomenclature. This study was conducted under the approval of the Ethics Committee of the Institution (CEUA/UFU 067/12).

\section{Results}

The femoral artery in crab-eating fox (Figures $1 \mathrm{~d}$ and 2c) rises as a distal continuation of the external iliac artery (Figures 1a and 2a), after crossing the inguinal canal.

After emerging through the superficial inguinal ring, in the proximal part of the femoral triangle, the femoral artery runs caudally and laterally from the base to the apex of the triangle. Initially, it is located slightly caudal to the sartorius muscle, and then inclines laterally and deepens until penetrating the adductor canal, between the cranial border of the adductor muscles and the caudal border of the vastus medialis muscle (Figure $1 \mathrm{am}$ and $1 \mathrm{vm}$ ). At the distal middle segment of the thigh, the femoral artery quickly deepens between the vastus medialis muscle and the adductor magnus muscle, crossing the adductor hiatus and enters in the popliteal fossa as popliteal artery (Figure 1j).

The first branch of the femoral artery that vascularizes the structures of the thigh is the deep femoral artery (Figures $1 \mathrm{~b}$ and $2 \mathrm{~b}$ ); however, it arises from the external iliac artery (Figures 1a and 2a) still in the pelvic cavity. 


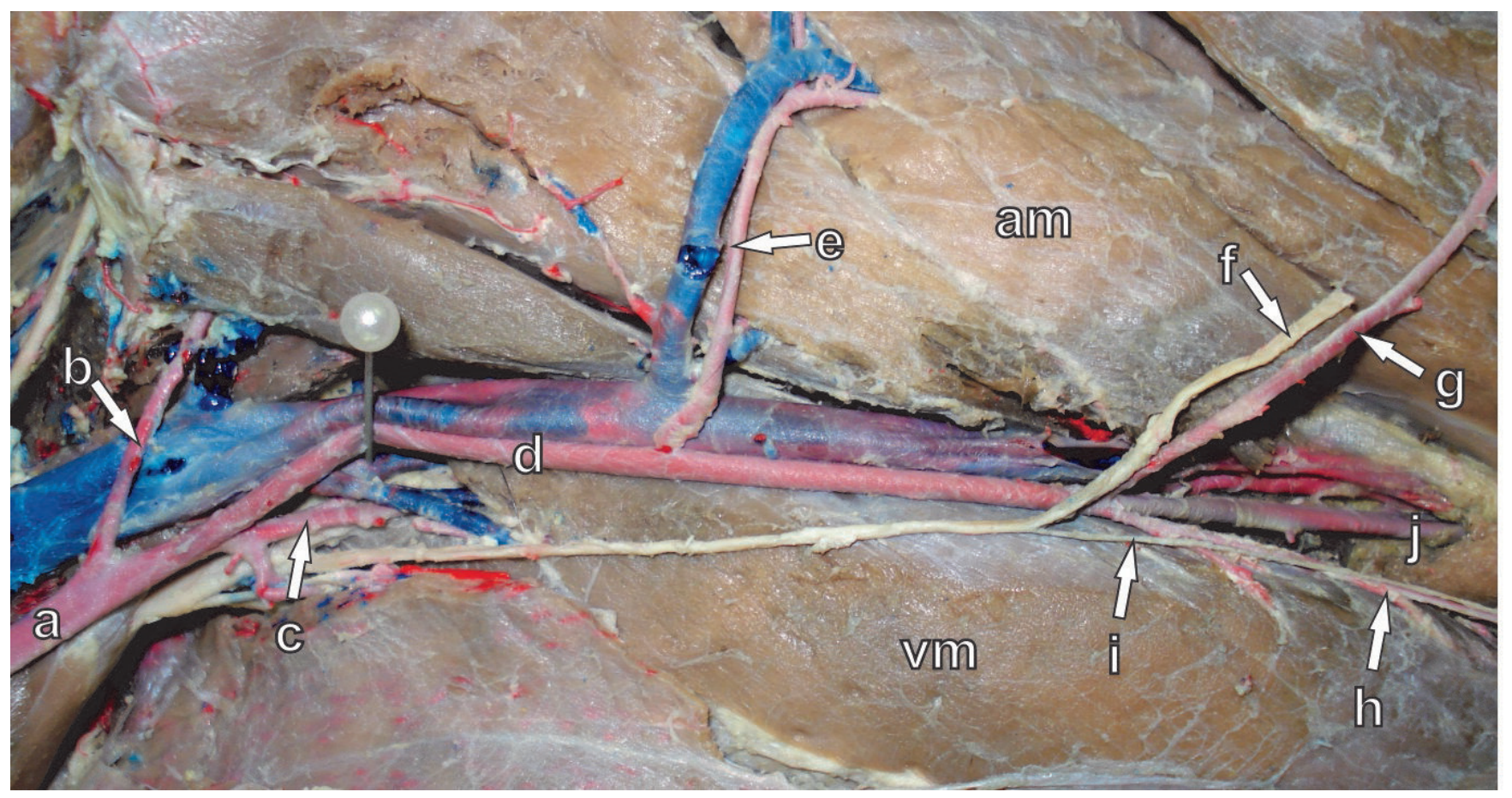

Figure 1 - Photographic image of arterial vascularization of the thigh in crab-eating fox: a - external iliac artery, b - deep femoral artery, c - lateral circumflex femoral artery, d - femoral artery, e - caudal femoral artery, $\mathrm{f}$ - saphenous nerve, $\mathrm{g}$ - saphenous artery, $\mathrm{h}$ - descending genicular artery, $\mathrm{i}$ - descending genicular nerve, $\mathrm{j}$ - popliteal artery, am - adductor magnus muscle, vm - vastus medialis muscle

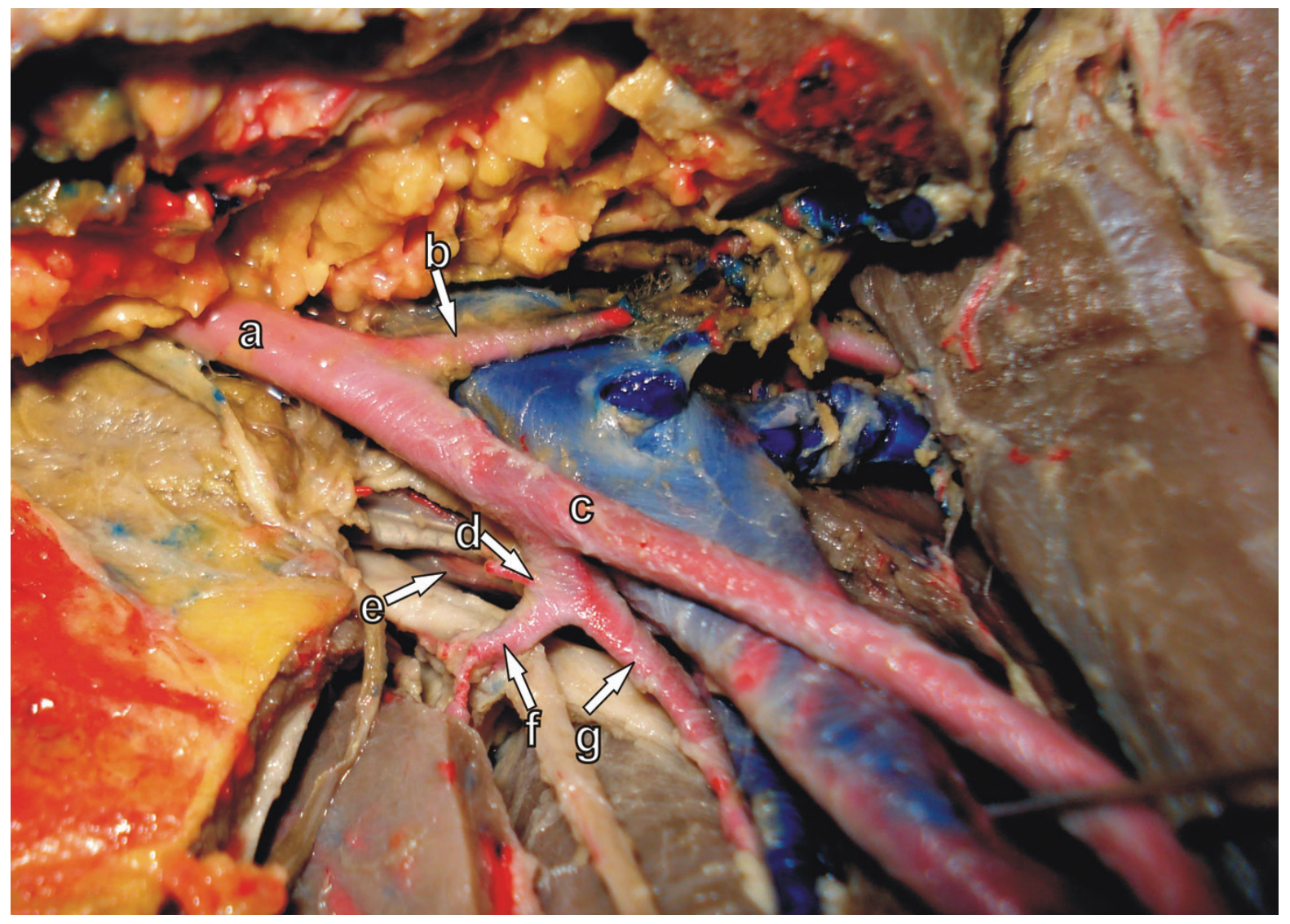

Figure 2 - Photographic image of arterial vascularization of the thigh in crab-eating fox: a - external iliac artery, b - deep femoral artery, c - femoral artery, d - lateral circumflex femoral artery, e - ascending branch of the lateral circumflex femoral artery, $\mathrm{f}$ - transverse branch of the lateral circumflex femoral artery, $\mathrm{g}$ - descending branch of the lateral circumflex femoral artery 
The first major branch of the femoral artery is the lateral circumflex femoral artery, which originates in the caudomedial face of the femoral artery in $100 \%$ of cases (Figures $1 \mathrm{c}$ and $2 \mathrm{~d}$ ). It passes between the divisions of the femoral nerve, and divides into ascending, transverse, and descending branches (Figures 2e, $2 \mathrm{f}$ and $2 \mathrm{~g}$ ). A few centimeters distal to the origin of the lateral circumflex femoral artery, the femoral artery emits only one caudal femoral artery (Figure $1 \mathrm{e})$, which is originated from the caudomedial face. The following branches of the femoral artery arise from the distal middle segment of the thigh: the saphenous artery (Figure $1 \mathrm{~g}$ ) originates from the caudomedial face and accompanies the saphenous nerve (Figure 1f); the descending genicular artery (Figure 1h) emerges at the point of origin of the saphenous artery and accompanies the descending genicular nerve (Figure 1i). Finally, the femoral artery runs distally through the adductor canal and enters the popliteal fossa as popliteal artery (Figure 1j).

In the hoary fox, the arterial pattern of the thigh is similar to that described in the crab-eating fox. The femoral artery (Figure 3e) originates as a continuation of the external iliac artery (Figure 3a) and the deep femoral artery (Figure $3 b$ ) rises from it, still in the pelvic cavity. The first branch of the femoral artery is a common trunk of the medial circumflex femoral artery and the lateral circumflex femoral artery (Figure $3 \mathrm{c}$ and $3 \mathrm{~d}$ ). Then, the femoral artery follows distally and caudally between adductor magnus and vastus medialis muscles (Figure $3 \mathrm{am}$ and $3 \mathrm{vm}$ ), emitting the proximal caudal femoral artery (Figure 3g), three muscular branches (Figure 3f), the distal caudal femoral artery (Figure 3h), the saphenous artery (Figure 3k), and the descending genicular artery (Figure $3 \mathrm{j}$ ). The femoral artery then enters the popliteal fossa as popliteal artery (Figure 3i).

In the maned wolf, the femoral artery (Figure 4e) represents the distal continuation of external iliac artery (Figure 4a) and begins behind the inguinal ligament. The deep femoral artery (Figure $4 \mathrm{~b}$ ) arises from the external iliac artery in the pelvic cavity.

The medial and lateral circumflex femoral arteries (Figure $4 \mathrm{c}$ and $4 \mathrm{~d}$ ) arise in the common trunk on the lateral side of the femoral artery. Both arteries are approximately the same size and are distributed in the usual way as those seen in the crab-eating fox. In the thigh, three muscular branches rise cranially from the femoral artery in maned wolf: proximal, medial, and distal (Figure 4f). On the other hand, only the caudal femoral artery rises from the caudal side (Figure $4 \mathrm{~g}$ ). The saphenous artery (Figure $4 \mathrm{~h}$ ) and the descending genicular artery (Figure 4i) rise in the distal segment of the thigh and then the femoral artery deepens entering the adductor canal and continues as popliteal artery (Figure 4j).

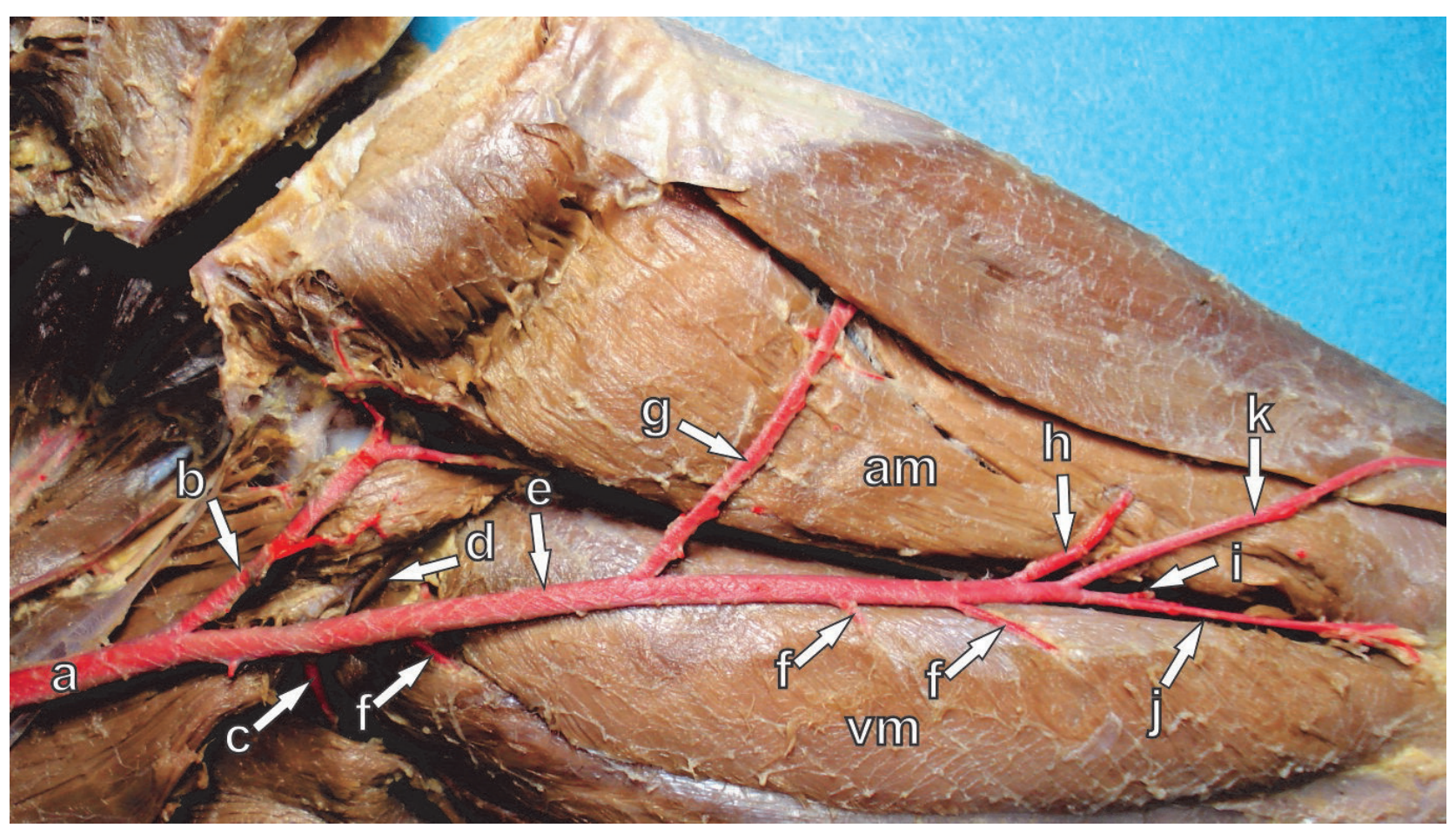

Figure 3 - Photographic image of arterial vascularization of the thigh in hoary fox: a - external iliac artery, b - deep femoral artery, c - lateral circumflex femoral artery, $\mathrm{d}$ - medial circumflex femoral artery, e - femoral artery, $\mathrm{f}$ - muscular branches, $\mathrm{g}$ - proximal caudal femoral artery, $\mathrm{h}$ - distal caudal femoral artery, i - popliteal artery, $\mathrm{j}$ - descending genicular artery, $\mathrm{k}$ - saphenous artery, am - adductor magnus muscle, vm - vastus medialis muscle 


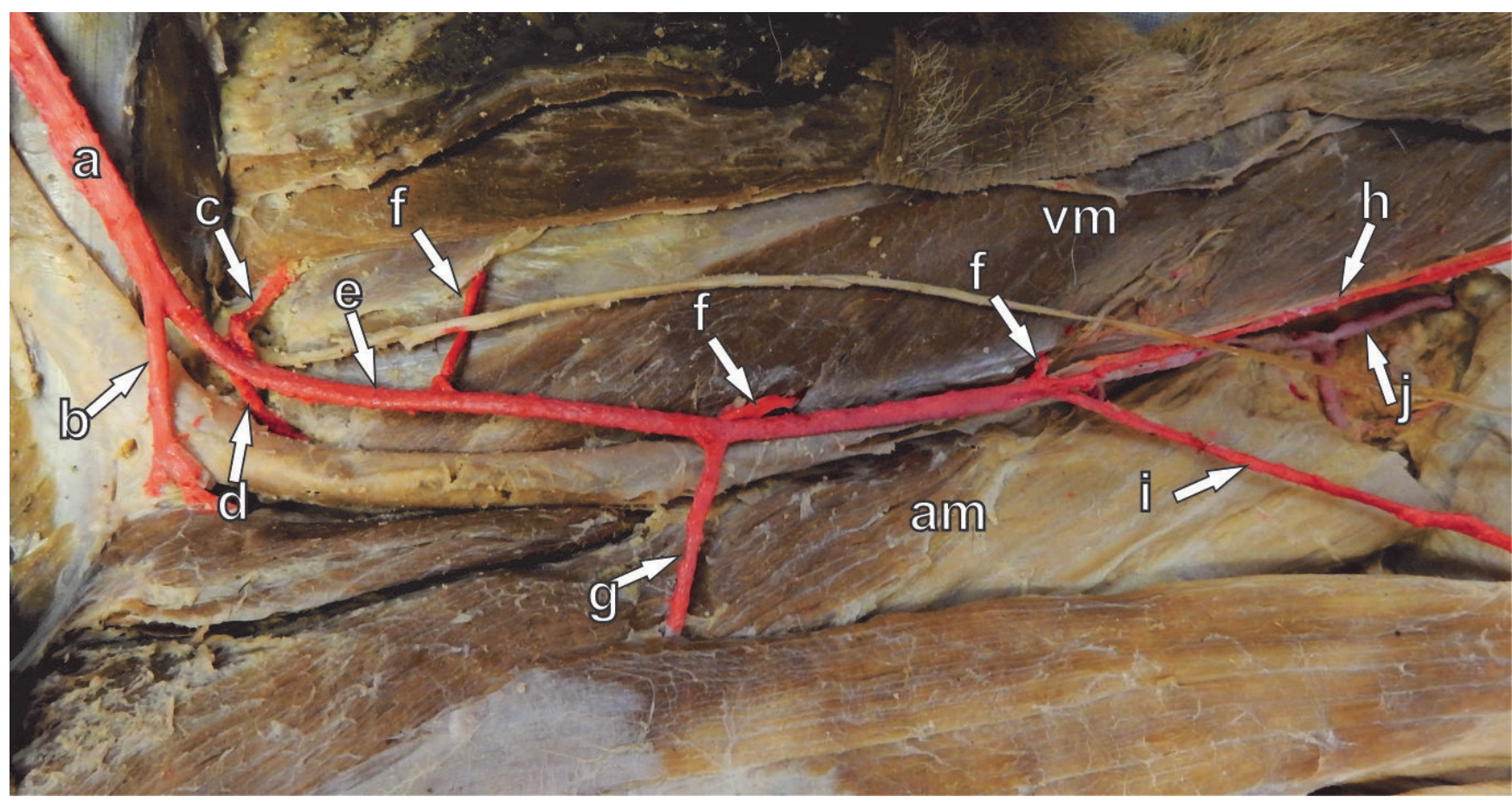

Figure 4 - Photographic image of arterial vascularization of the thigh in maned wolf: a - external iliac artery, b - deep femoral artery, c - lateral circumflex femoral artery, d - medial circumflex femoral artery, e - femoral artery, $\mathrm{f}$ - muscular branches, g - caudal femoral artery, h - saphenous artery, i - descending genicular artery $\mathrm{j}$ - popliteal artery, am - adductor magnus muscle, vm - vastus medialis muscle

Table 1 summarizes the anatomy of the femoral artery found in crab-eating fox, hoary fox, and maned wolf.

Table 1 - Anatomic characteristics of the femoral artery found in crab-eating fox, hoary fox, and maned wolf

\begin{tabular}{|c|c|c|c|}
\hline & Crab-eating fox & Hoary fox & Maned wolf \\
\hline Origin & external iliac & external iliac & external iliac \\
\hline \multirow{9}{*}{ Branches } & deep femoral & deep femoral & deep femoral \\
\hline & lateral circumflex femoral & lateral circumflex femoral & lateral circumflex femoral \\
\hline & \multirow{3}{*}{ caudal femoral } & medial circumflex femoral & medial circumflex femoral \\
\hline & & proximal caudal femoral & caudal femoral \\
\hline & & distal caudal femoral & \\
\hline & & muscular branches & muscular branches \\
\hline & saphenous & saphenous & saphenous \\
\hline & descending genicular & descending genicular & descending genicular \\
\hline & popliteal & popliteal & popliteal \\
\hline
\end{tabular}

\section{Discussion}

Although there are scarce data on wild-animal macroscopic anatomy available in the literature, some citations on the femoral artery were compiled and will be confronted with the results of this study. The contextualization of information on the relationship between the environment and the fauna can be of great importance (OLIVEIRA et al., 2004). It is possible to go further in these considerations and state that it is essential and even indispensable, since the life of the components of a biome is strictly associated with this interaction.

Cerrado canids are relatively fragile species, mainly because their food resources are highly specialized. Thus, the fast development of human activities in the biome produces great pressure on these groups, leading them towards extinction. Cerrado is a biome of high complexity subjected to an increasing anthropogenic pressure, forcing 
the migration of many species and their coexistence with other groups, requiring adaptations related to survival and reproduction. Ribeiro-Junior and Bertoluci (2009) report that only $2 \%$ of the Cerrado area is under the protection of conservation units, reflecting the lack of programs of protection and preservation. The importance of this study is related to this context since programs of protection and conservation of wildlife involve knowledge of the biology of its components.

The anatomical organization of terrestrial mammals follows a baseline, maintaining anatomical structures that perform similar functions with few alterations, but variations may be frequent, following mainly the adaptations needed for better functional performance. The bodies of the specimens studied in this work have a relative structural symmetry; in general, both antimeres show morphological similarities, but variations may occur. According to Poirier (1912), Huber (1941) and Massoud and Fletcher (1997), all cited by Otag et al. (2012), arterial variations are usually bilateral. However, no relationship of laterality on the morphologic aspects studied in this work was observed.

The comparative analysis among neotropical canids (crab-eating fox, hoary fox, and maned wolf) shows that the femoral artery is the continuation of the external iliac artery after its passage through the inguinal canal in all the specimens studied. These observations are in agreement with Hill (1972) in Alouatta and Lagothrix, Testut and Latarjet (1979), and Tanyeli et al. (2006) in humans, Barbosa (2001) in capuchin monkey, Krakenberg et al. (2006) in Anubis, Rhesus, Cynomolgus, Cyclopis and humans, Getty (1986) in domestic mammals, and AversiFerreira et al. (2013) in Sapajus libidinosus.

Regarding the branches of the femoral artery, Testut and Latarjet (1979), Lippert and Pabst (1985) in humans, Hill (1972) in non-human primates, and Barbosa (2001) in capuchin monkey report that the deep femoral artery arises from the femoral artery. However, in neotropical canids, its origin occurs in the external iliac artery, still in the pelvic cavity, as described by Getty (1986) in domestic animals. We believe that the site of origin of the deep femoral artery may be associated with postural differences between primates and non-primates. The erect posture verified in these primates requires considerable adaptations of the pelvic and thigh muscles, leading to a different model for the blood supply of the anatomical structures involved. There are many anatomical variations of the femoral artery and its branches (HILL, 1972; TESTUT; LATARJET, 1979;
BARBOSA, 2001; REARDON et al., 2004; FUKUDA et al., 2005; TANYELI et al., 2006; GETTY, 2008; KUMAR et al., 2011; OTAG et al., 2012; AVERSI-FERREIRA et al., 2013), but no reference is done to possible association with evolutionary aspects.

The lateral and medial circumflex femoral arteries, when present in neotropical canids, have their positions varying from dorsal, lateral to medial at the proximal segment of the femoral triangle. These arteries can be originated separately or in a common trunk between them or with other arteries. This behavior is in agreement with Hill (1972) and Dyl and Topol (2007) in non-human primates, Testut and Latarjet (1979) and Tanyeli et al. (2006) in humans, Barbosa (2001) and Aversi-Ferreira et al. (2013) in capuchin monkey, and Krakenberg et al. (2006) and Getty (1986) in domestic animals. The same authors describe, in primates and non-primates, the trajectory of the femoral artery within the femoral trigone from proximal to distal, lateral and caudally, until penetrating the adductor canal. These findings are consistent with observations in neotropical canids.

In neotropical canids, the lateral and medial circumflex femoral arteries, in $75 \%$ of cases, arise isolated from the femoral artery, but in hoary fox, $25 \%$ of cases show a common trunk. These findings are in agreement with Hill (1972) in non-human primates and Testut and Latarjet (1979) in humans, when they say that the lateral and medial circumflex femoral arteries can form a common trunk between each other or with the deep femoral artery. In humans and other primates or domestic animals the circumflex femoral arteries are always present (HILL, 1972; TESTUT; LATARJET, 1979; GETTY, 1986; BARBOSA, 2001).

Massoud and Flecher (1997) and Williams et al. (1934) argue that arterial variations are not sex-related, but Suder and Nizankwski (1985) and Başar et al. (2002) describe this relationship. We dissected specimens of both sexes, but we found no such association in neotropical canids.

Regarding the muscular branches of the femoral artery, their presence is variable in neotropical canids, and they were not found in crab-eating fox when the vascularization of the muscles was performed by branches of the deep femoral artery and the circumflex femoral arteries. They are, however, relatively numerous in hoary fox and maned wolf. Testut and Latarjet (1979), Barbosa (2001), and Getty (1986) state that these variations may be present in humans and domestic animals. 
The literature on human and non-human primates cites the muscular branches of the femoral artery simply as "muscle branches" which are variable in number (HILL, 1972; TESTUT; LATARJET, 1979; BARBOSA, 2001; KRAKENBERG et al., 2006). In domestic animals, Getty (1986) describes two muscular branches as the proximal caudal femoral artery and distal caudal femoral artery. In neotropical canids, both arteries are observed only in the hoary fox. In the crab-eating fox and the maned wolf only one caudal femoral artery is present and, judging by its location, it is the proximal artery.

The last branches of the femoral artery in neotropical canids are the saphenous artery and the descending artery of the knee, data consistent with Hill (1972), and Dyl and

\section{References}

AVERSI-FERREIRA, R. A. G. M. F.; ABREU, T.; PFRIMER, G. A.; SILVA, S. F.; ZIERMANN, J. M.; SILVA, F. O. C.; TOMAZ, C.; TAVARES, M. C. H.; MAIOR, R. S.; AVERSI-FERREIRA, T. A. Comparative anatomy of the hind limb vessels of the bearded capuchins (Sapajus libidinosus) with apes, baboons, and Cebus capucinus: with comments on the vessels' role in bipedalism. Journal of Biomedicine and Biotechnology, v. 2013, article 737358, 2013. doi: $10.1155 / 2013 / 737358$.

BARBOSA, L. Padrão vascular arterial da coxa do macaco Cebus apella (macaco-prego). 2001. 76 f. Dissertação (Mestrado em Biologia e Patologia Bucodental) - Faculdade de Odontologia de Piracicaba, Universidade Estadual de Campinas, Piracicaba, 2001.

BAŞAR, R.; SARGON, M. F.; CUMHUR, M.; BAYRAMOĞLU, A.; DEMIRYÜREK, D. Distinct intergender difference in the femoral artery ramification patterns found in the Turkish population: angiographic study. Anatomical Science International, v. 77, n. 4, p. 250-253, 2002. doi: 10.1046/j.0022-7722.2002.t01-100015.x.

CHIARELLO, A. G.; AGUIAR, L. M. S.; CERQUEIRA, R.; MELO, F. R.; RODRIGUES, F. H. G.; SILVA, V. M. F. Mamíferos ameaçados de extinção no Brasil. In: MACHADO, A. B. M.; DRUMMOND, G. M.; PAGLIA, A. P. (Ed.). Livro vermelho da fauna brasileira
Topol (2007) in non-human primates, Testut and Latarjet (1979) and Tanyeli et al. (2006) in humans, Barbosa (2001) and Aversi-Ferreira et al. (2013) in capuchin monkey, and Krakenberg et al. (2006) and Getty (1986) in domestic animals. After the origin of these arteries, the femoral artery rapidly deepens in the caudal-lateral direction, passing through the adductor canal to enter the popliteal fossa as popliteal artery.

\section{Conclusion}

The anatomy of the femoral artery in neotropical canids is closely similar to that in domestic canids; however, small differences inherent to each species are present.

ameaçada de extinção. Brasília, DF: Ministério do Meio Ambiente; Belo Horizonte: Fundação Biodiversitas, 2008. p. 681-702.

DYL, $Ł . ;$ TOPOL, M. The femoral artery and its branches in the baboon Papio Anubis. Folia Morphologica, v. 66, n. 4, p. 291-295, 2007.

FUKUDA, H.; ASHIDA, M.; ISHII, R.; ABE, S.; IBUKURO, $\mathrm{K}$. Anatomical variants of the lateral femoral circumflex artery: an angiographic study. Surgical and Radiologic Anatomy, v. 27, n. 3, p. 260-264, 2005. doi: 10.1007/s00276004-0312-5.

GANEM, R. S. Conservação da biodiversidade: legislação e políticas públicas. Brasília, DF: Câmara dos Deputados, 2011.

GETTY, R. Sisson/Grossman: anatomia dos animais domésticos. 5. ed. Rio de Janeiro: Guanabara Koogan, 1986. v. 3.

HILL, W. C. O. Primates: comparative anatomy and taxonomy. Edinburgh: Edinburgh University Press, 1972. Tomo V, Cebidae, Part B.

INTERNATIONAL COMMITTEE ON VETERINARY GROSS ANATOMICAL (ICVGAN). Nomina Anatomica Veterinaria. 5. ed. Hannover: Committee, 2012. 
KRAKENBERG, H.; SCHLUTER, M.; SCHOFER, J.; TUBLER, T. Die Femoralarterie: das komplexeste periphere Gefäß. Herz Kardiovaskuläre Erkrankungen, v. 31, p. 137-141, 2006. doi: 10.1007/s00059-006-2796-8.

KUMAR, V.; KUMAR, V. V.; MURLIMANJU, B. V.; NAVEEN, N. S. High origin of the deep femoral artery: a case report and literature review. Jornal Vascular Brasileiro, v. 10, n. 3, p. 243-245, 2011. doi: 10.1590/S167754492011000300010 .

LIPPERT, H.; PABST, R. The profunda femoris artery. In: LIPPERT, H.; PABST, R. Arterial variations in man: classification and frequency. Munich: Bergman., 1985. p. 61.

MASSOUD, T. F.; FLETCHER, E. W. L. Anatomical variants of the profunda femoris artery: an angiographic study. Surgical and Radiologic Anatomy, v. 19, n. 2, p. 99-103, 1997. doi: 10.1007/s00276-997-0099-2.

OLIVEIRA, C.; TEIXEIRA, R. A. P.; CONCHALO, W. L. Uma abordagem contextualizada da anatomia humana e comparada. In: PRÓ-REITORIA DE GRADUAÇÃO DA UNIVERSIDADE ESTADUAL PAULISTA. Núcleos de Ensino. São Paulo: Unesp, 2004. p. 291-310. Available from: <http://bit.ly/2fj22gA >. Viewed: 20 Jan. 2014.

OTAG, I.; ÇIMEN, M.; SOLAK, O.; OTAG, A.; ÇIMEN, F. G.; KOSAR, M. I. Absence of the arteria profunda femoris. International Journal of Morphology, v. 30, n. 2, p. 428-431, 2012. doi: 10.4067/S071795022012000200012 .

REARDON, C. M.; O'CEALLAIGH, S.; O'SULLIVAN, S. T. An anatomical study of the superficial inferior epigastric vessels in humans. British Journal of Plastic Surgeons, v. 57, n. 6, p. 515-519, 2004. doi: 10.1016/j. bjps.2004.04.019.

RIBEIRO-JUNIOR, J. W.; BERTOLUCI, J. Anuros do cerrado da Estação Ecológica e da Floresta Estadual de Assis, sudeste do Brasil. Biota Neotropica, v. 9, n 1, p.207-216,2009. doi: 10.1590/S1676-06032009000100020.

SUDER, E.; NIZANKOWSKI, C. Variations in the origin of the deep femoral arteries in human fetuses. Folia Morpholica, v. 44, n. 3-4, p. 262-269, 1985.

TANYELI, E.; YILDIRIM, M.; ÜZEL, M.; VURAL, F. Deep femoral artery with four variations: a case report. Surgical and Radiologic Anatomy, v. 28, n. 2, p. 211-213, 2006. doi: 10.1007/s00276-005-0072-x.

TESTUT, L.; LATARJET, A. Tratado de anatomia humana. Barcelona: Salvat, 1979.

WILLIAMS, G. D.; MARTIN, C. H.; MCINTIRE, L. $\mathrm{R}$. Origin of the deep and circumflex group of arteries. Anatomical Record, v. 60, n. 2, p. 189-196, 1934. doi: 10.1002/ar.1092120216. 